\section{The Troops in Santiago.}

Near Santiago, July 13, 1898.

[Delayed in Transmission.]

To the Editor:- Since my last on the $2 \mathrm{~d}$ inst., yellow fever with its usual attendant scare has made its appearance in the camp of our army, nor is it anything but as a natural sequence of the violation of both the laws of health and ordinary precaution.

After notiflcation to Spanish authorities that Santiago would be bombarded after twenty-four hours the foreign consuls in the city asked permission to let non-combatants and foreigners pass out. General Shafter granted the request, which was perfectly proper and most humane, but the great and inexcusable mistake was to allow them to pass through and disseminate among our camps and to have them hauled in our commissary wagons to Siboney, some nine miles distant, where is located our general hospital and the point of debarkation of troops and the embarking of our sick and wounded. There are two roads leading to the northwest and north of Santiago where refugees could have gone and our troops would have been safe from contagion.

Now to siightly recapitulate, for in my last I mentioned the want and great need of proper army sanitation. On landing, both at Baiquiri and Siboney, our soldiers were allowed to enter and dwell in abandoned shanties, for that is true of the so-called houses. At Siboney two of the houses were converted into hospitals for the reception of the wounded from the battle of La Guacima. In one room were four cases of measles within six feet of the wounded. No doors closed any of the openings in the house. Soldiers were pushed rapidly along, advancing without sufficient food, as the commissary department was landing supplies very slowly indeed. There was and is bitter complaint about the commissary department. The sun was quite warm and the troops marching rapidly on scant food-frequently a few hard tacks and water their only sustenance for twentyfour hours or more-were unable to carry their rolls, hence they threw them aside; the result is that many soldiers are sleeping in the open air and on the damp ground. Hospital tents had been established by Dr. Cooke two miles and a half west of San Juan Hill, where General Hawkins made his brave charge, but the conflict was so fierce that the tente were soon inadequate for the wounded, and as tents were still on board the ships, poor wounded soldiers were compelled to lie on the wet ground for days, when they were removed to Siboney to the general hospital. Ambulance service was very good, but the supply of ambulances was too limited; the result was that one-half the wounded were hauled from the temporary field hospital to the division hospital in commissary wagons, which caused great suffering. As I dressed the wounded for two successive nights I speak from observation.

The pits for feces were not dug for several days after the canvas was pitched, hence an unpleasant odor from every thicket. The wounded were compelled to go from twelve to twenty-four and in some cases thirty hours without sufficient food. Their appeals for soup or something to eat when I would go among them can never be forgotten. The attending surgeons did all in their power to relieve the distreas, but they had not the supplies sufficient.

The fever cases, not yellow fever, but fever caused by hot sun, bad water, sleeping unprotected, and last, but not least, from scant food, are now in little shelter tents only a hundred feet from my tent. The number of this class of cases is increasing rapidly. At this writing there are over 200 casee. Just across a little pathway there are eight more shelter tents and in these there are six cases of yellow fever and two cases of sus pected fever with no precautions whatever to prevent contagion, for along this path soldiers all pass every few moments. Just to the east and not 200 feet away, is where the pack mules and commissary wagons camp nightly, all on a level and open ground where the water is now standing from one inch to four inches deep ; this water slowly drains along between and in to the tents of the sick. There are plenty of hills and mountain sides near where comfortable tents could be located. No pest house has yet been established at this camp. At Siboney one has been established for nearly a week. Just south of the general hospital at Siboney and across the railroad track is a coral reef too high for the sea waves to wash over it. This reef is the nocturnal privy, and is one extended mass of filth, and effort is made to prevent it, although two pits are near. Despite all the bad hygienic conditions the wounded are improving more rapidly than under more favorable conditions at home. Of the surgery and fevers will write in my next; will state however that perhaps up to date 200 cases of yellow fever is a large estimate. With rare exceptions the cases are very mild.

The scare is worse than the disease, and want of hygiene worse than all.

Orlando Ducker, M.D.

\section{Dr. Scheppegrell's Book.}

New Orleans, Sept. 6, 1898.

To the Editor:-On my return to the city, a few days ago, I noted the reference to my recently published work on "Electricity in the Diagnosis and Treatment of Diseases of the Nose, Throat and Ear," among the Book Notices in your issue of August 20.

An author naturally expects various kinds of criticisms, but the writer in medical literature has reason to believe that his work will receive fair attention at the hands of the more important medical journals, and that the criticisms will be made by some one competent to judge of the merits or defects of his work.

In the case of the Journal of the A merican Medical As. Sociation, there is, according to my opinion, more than the usual relation between subscriber and editor. This journal is the official organ, in fact the mouth-piece, of the AMERICAN Medical Association. In other medical publications, if the reader objects to the methods of the periodical, he simply cancels his subscription; with the Journal of THE AmERICAN Medical Association, however, the journal is part of the organization, and cancellation of the subscription is practically a resignation of membership. The editor, in fact, holds his office, not through the good-will of the publisher, but by the vote of the members or their representatives. When, therefore, an article is submitted for publication, or a work for criticism, it is entitled, not only to the courtesy of the editor to a subscriber, but also of an officer of an association to one of its members.

In the case of my work, which was sent you, I will admit that it refers to a special part of medicine, namely, of the nose, throat and ear, to which a physician devoting his time to general medicine would scarcely be expected to make a fair criticism. Not only is this the case, but it refers especially to electricity in this department, of which even a specialist in nose and throat diseases might hesitate to venture an opinion of its merits. Under the circumstances, therefore, had the Journal simply given the name and title of the work, this would have answered the purpose, and it would not at least have given an erroneous impression. On the other hand, there are many men in Chicago who would have been able to criticise this work with credit to themselves and with justice to the author.

In your criticism, the only part that refers to the work is the first paragraph: "The illustrations in this book are fair, and the printing is well done. The book is printed on good paper." This is as much to the point as if an artist had sub. mitted a painting and the critic had reported that the canvas was fair, the paint well prepared, and the frame good.

The other paragraph has no reference to the work whatever. It is simply a succession of generalities, which might refer to 
any work on electro-therapeutics, and which belongs to a method now out of date. The reader expects not generalities, proven to be more than a coincidence. Some years ago a but a weighing of the good and bad points of the work which dentist in our city had a young woman in his employ to assist a journal undertakes to criticise.

Not only is the criticism vague, but it is limited to the subject of electro-therapeutics, which forms but a minor part of the work. Had the critic, instead of limiting his attention to the "illustrations, printing and paper," read the work, or at least looked over the table of contente, he would have convinced himself that electro-therapeutice forms but a small part of the work; a large proportion refers to the subject of electro-physics, which has been reduced to as scientific a basis as any other department of physics. The subject of electric illumination and transillumination is no longer one of controversy, but is now almost universally advocated. Electrolysis, cataphoresis and massage, by means of electric appliances, belong more to electro-surgery than to electro-therapeutics, and the subject of the $\mathrm{X}$-rays has passed beyond its experimental stage, and is now admitted as a useful procedure in hospitals and medical colleges.

The book has only recently been published, and I have thus far seen but three criticisms in addition to a number of simple notices. Of the three criticisms referred to, one is in your journal, August 20 ; the second is in the Journal of Eye, Ear and Throat Diseases, Baltimore, July, 1898, and the third in the Memphis Medical Monthly, September, 1898. I herewith enclose a copy of the second and third ciriticisms, which bear on their face the evidence of a careful reading of the matter and a weighing of its merits. They form a strong contrast with the vapid generalities in the official organ of the AMERIcan Medical Association. Yours very truly, (Dictated.) W. ScheppegrelL, M.D.

[Enclosures: Extract from Journal of Eye, Ear and Throat Diseases, July, 1898. Extract from Memphis Medical Monthly, September, 1898.]

ANswer.-This journal has not space to do more than give brief "notices." It rarely prints "reviews." The aim is to inform the reader what the contents are. In this case the title was sufficiently explicit. The manner in which the publisher performs his part of the book-making is not a matter of indifference, but a proper subject of praise or censure. Nothing was said to the detriment of Dr. Scheppegrell's excellent work in our notice, which is now given the additional notice its author desires.

\section{Hospital at Fort Myer.}

\section{U. S. General Hospital, Fort Myer, Va.} A ug. 30, 1898.

To the Editor:-We have here a magnificent hospital under the command of Major and Surgeon W. B. Davis, U. S. A., whose earnest work is making this one of the finest hospitals in the country.

We have about four hundred patients, and one ward containing 200 beds as yet not entirely filled. This ward I believe to be the largest in the world.

Most of our patients are typhoid, and every material is at the hands of the surgeon in charge with which to do his work.

The charges and criticism relative to improper food and attendance is, in the case of this hospital, a falsehood, and I believe it to be so in the others, for as rapidly as possible every thing is being accomplished for our sick soldiers.

$$
\text { Respectfully, }
$$

D. H. Lamb,

Acting Assistant Surgeon, U. S. A., formerly of Owosso, Mich.

Is there Danger in Employment of Female Assistants by Dental Surgeons?

LA Porte, Ind., Sept. 12. 1898. in his surgical operations. After remaining in the office several years she was married, and in due time an infant appeared upon the acene with a hare lip and cleft palate. The young woman who next assumed her duties in the office remained eight years, when she became a wife, and recently gave birth to a daughter with the same horrid deformity. I would like to hear from the profession if similar cases are on record.

E. L. AnNis, M.D.

\section{PUBLIC HEALTH.}

Governor Tanner has appointed Dr. A. C. Corr, of Carlinville, to the vacancy in the Illinois Board of Health. He was last year President of the Illinois State Medical Society, and it is understood that he will be the next President of the Board.

How to Use Millions Usefully Against Tuberculosis. - The editor of the London Practitioner reminds his readers that some years ago a millionaire, burdened beyond most of his kind with a sense of the duties of his position and fortune, asked through a newspaper for suggestions as to the employment of his wealth in the way likely to be most beneficial to the public. For some reason or other nothing came of it. If such a question were asked again, I should unhesitatingly answer that there could be no better object than the foundation of properly equipped sanatoria in this country for poor sufferers from phthisis. That the public, if appealed to in the right way, would help liberally is not to be doubted. The manner in which they support consumption hospitals shows that their help might be counted upon in an active crusade againgt the disease. But the question is not one of merely philanthropic interest; it is of national importance, as it closely concerns the maintenance of the vigor of the race. On this ground the cooperation of the State might well be asked. In this country it is notoriously difficult to get even enlightened statesmen to attend to anything out of which party capital can not be made. But even here the day is surely, if somewhat slowly, coming when ordinary legislators will be brought to recognize that the public health is the first and greatest of political questions. Let us, in short, have a national crueade against a national disease.

The Plague in India.-It is discouraging to learn, as we do by telegraph, that after all that has been done for Bombay in the way both of curative and of preventive measures, the plague has broken out afresh in that unhappy city. As yet, it is true, there is nothing alarming in the reports that have reached this country; for these speak of an increase of mortality from this source of only about 20 per cent., as compared with the figures for the corresponding weeks of last year. But the distressing thing is that there should have been an increase at all, when we might so reasonably have looked for a decrease, if not even for an entire stamping out of the germs of this disease. For the most recent advances in the science of bacteriology have been brought to bear by some of the most skilled European experts, on the vital problem presented by the condition of Bombay. All the tried and prophylactic measures have been put into force there and the whole power of the government has been placed at the disposal of the health officers, who have been doing such valiant battle with their insidious foe; but the results show that when it has once found a congenial environment the expelling of it is very far from being an easy task. Some parts of the city, it is said, have been so completely changed by the clearing away of plague-infected dwellings that it would be difficult for an old residenter, in paying the place a visit after an absence of a year or two, to recognize localities with To the Editor:- Should dental surgeons employ female which he was, until recently, most familiarly acquainted. It 